FACTA UNIVERSITATIS

Series: Physical Education and Sport, Vol. 18, No 2, 2020, pp. 355 - 369

https://doi.org/10.22190/FUPES200826033S

Research article

\title{
FEEDBACK USE AND PERCEPTIONS OF PHYSICAL EDUCATION PRE-SERVICE TEACHERS
}

\author{
UDC 796.01.015 \\ 796.356 .361
}

\section{Michael Spittle, Sharna Spittle, Kelly Ruecker, Janet Young}

Institute for Health and Sport, Victoria University, Melbourne, Victoria, Australia

\begin{abstract}
The purpose of this study was to explore the use of feedback and perceptions of the use of feedback by pre-service teachers in peer-teaching (instructing their peers in university classes) and practical placement settings (teaching in schools). Pre-service teachers specializing in primary physical education (PE) and one other teaching method $(n=59)$ were observed while teaching a 15-minute lesson in a peer-teaching setting, with six participants also observed while teaching on practical placement. Participants retrospectively recalled the feedback they perceived providing during the lesson. Average feedback frequency rate was once every 56 seconds in peer-teaching and once every 86 seconds in practical placement. The most common type of feedback provided was verbal, non-skill related, positive feedback. Pre-service teachers perceived that they provided feedback significantly more often than they actually did (every 41 seconds versus every 56 seconds in peer-teaching). In peer-teaching, pre-service teachers perceived that they provided significantly more non-verbal, negative, knowledge of results, descriptive, and corrective types of feedback than they actually provided, whereas they perceived that they had provided significantly less verbal, non-skill related, positive, knowledge of performance, prescriptive, and terminal types of feedback than they actually provided $(p<01)$. Pre-service teachers provided feedback frequently in peer-teaching and practical placement settings, but less often in practical placement than peer-teaching. Actual and perceived feedback frequencies differed significantly and suggest that preservice teachers may not always be aware of how often and the type of feedback they are providing, highlighting that PE teacher education programs may need to work with preservice teachers to develop self-awareness.
\end{abstract}

Key words: Knowledge of Performance, Knowledge of Results, Teacher Effectiveness, Physical Education, Motor Learning

Received August 26, 2020 / Accepted September 10, 2020

Corresponding author: Michael Spittle

Institute for Health and Sport, Victoria University, PO Box 14428, Melbourne, VIC, 8001, Victoria, Australia

Phone: + $61399192685 \cdot$ E-mail: michael.spittle@vu.edu.au

(C) 2020 by University of Niš, Serbia | Creative Commons License: CC BY-NC-ND 


\section{INTRODUCTION}

Providing feedback to students during physical education (PE) is considered to be an essential teacher behavior influencing time on task, participation, and student motivation as well as skill acquisition. The provision of feedback to learners has been studied extensively in motor learning and skill acquisition as well as discussed widely in pedagogy literature (Maksimović, \& Osmanović, 2018; Rink, 2020). Although feedback is perceived as important to learning in PE, studies have rarely described teachers who actually provide feedback, so we have limited practical understanding of the use of feedback in PE. In PE, the provision of feedback is often prescribed as part of education and evaluation of preservice teachers (Rink, 2020). It is also commonly listed as a key component of professional standards for PE teachers (Australia Institute for Teaching and School Leadership, 2011). Thus, researchers, theorists, and practitioners have identified providing feedback as important in teacher effectiveness.

Teacher effectiveness in PE can be conceptualized narrowly in terms of student and teacher behaviors related to producing student outcomes (Rink, 2014), with teacher evaluation often focused on teacher process variables including the provision of feedback (Ward, 2014). Much of the teacher effectiveness research in PE has been based on teacher processes, with outcomes aligned to the direct instructional approach, which emphasizes the provision of feedback (Metzler, 2014).

\section{Feedback}

Feedback is information that the learner receives about their performance. In PE, this is often called teacher feedback (Lee, Keh, \& Magill, 1993), while in motor learning, feedback provided by a teacher or coach is termed augmented (or extrinsic) feedback (Magill \& Anderson, 2020). Motor learning researchers have been interested principally in the use of feedback to improve skill performance (Rink, 2003); however, PE researchers have distinguished between feedback about the skill and more general feedback (van der Mars, Vogler, Darst, \& Cusimano, 1998; Fredenburg, Lee, \& Solmon, 2001). Thus, feedback could be skill-related (feedback that has information about the performance of the skill or knowledge required to perform the task) or non-skill related (feedback that does not give information specifically about performance of the skill, including positive forms of encouragement or motivation or negative forms of punishment or behavior correction) (Spittle, 2013; Magill \& Anderson, 2020).

Skill-related feedback in motor learning is often classified and described in terms of whether it provides information about the outcome of performance (Knowledge of Results$\mathrm{KR}$ ) or the process of performing the skill (Knowledge of Performance-KP) (Magill \& Anderson, 2020). Irrespective of the importance placed upon KR and KP in the motor learning literature, researchers in PE have rarely investigated the use of $\mathrm{KR}$ and $\mathrm{KP}$ in practice. Skill-related feedback can also be descriptive, prescriptive, or corrective. Descriptive feedback refers to feedback that describes an error in performance without evaluation (Spittle, 2013). Prescriptive feedback provides information that prescribes how to make a performance better (Spittle, 2013). Corrective feedback refers to a combination of both descriptive and prescriptive feedback, that is, an error is outlined and a correction is provided (Silverman, Tyson, \& Krampitz, 1992). 


\section{Feedback frequencies}

Just as the type of feedback provided can vary, when feedback is provided (timing) and how often feedback is provided (frequency) can vary. Concurrent feedback is provided during the performance of a skill, whereas terminal feedback is provided after the performance of a skill (Magill \& Anderson, 2020). The feedback frequency that generates the most effective learning of movement skills varies (Magill \& Anderson, 2020) and studies in PE on relationships between the amount of feedback provided by teachers and student performance have been equivocal (see Lee et al., 1993; Silverman, 1994; Rink, 2020). Early theorists and researchers believed that higher frequencies improved motor learning, and in PE the notion that providing more feedback was better also emerged (Silverman, 1994). Providing feedback less frequently, however, encourages the learner to engage in more active learning processes and, potentially, try alternative and potentially more effective learning strategies (Salmoni, Schmidt, \& Walter, 1984; Winstein \& Schmidt, 1990). In addition, in PE, what was once deemed to be most effective, that is higher feedback frequencies, was aligned most often with more with direct instructional models, rather than other instructional models (Metzler, 2011; 2014).

Much of the research on feedback frequency has examined the influence that feedback has on the learner (e.g., Kernodle \& Carlton, 1992; Koka \& Hein, 2005), not on the type and frequency of feedback actually provided by a teacher. Motor learning studies have predominantly been conducted in controlled, laboratory settings with feedback frequency of each individual learner regulated. Few studies have been conducted in PE settings, and the studies that have been reported in the literature have generally utilized classes that have been structured and designed by the experimenters. Researchers have rarely investigated how teachers provide feedback in PE when not provided with explicit instructions on feedback provision. Thus, our understanding of how often and what types of feedback are provided in PE is limited. In addition, researchers have not concentrated on how pre-service teachers, as opposed to in-service teachers, use feedback in their teaching.

The limited and often dated available research on feedback frequencies in PE, suggests that teachers do provide feedback frequently, that is, it is provided at a frequency of more than once per minute. An early review of research suggested that in general, teachers provided feedback as often as 30-60 times throughout a 30-minute lesson (Siedentop, 1991), with more recent data largely confirming this review (Behets, 1997; Spittle, Kennedy, \& Spittle, 2012). For example, Fishman and Tobey (1978) found that PE teachers provided feedback at rates above once per minute, with KP provided $94 \%$ of the time. Silverman and associates (1992) and Silverman, Woods, and Subramaniam (1998) reported that teachers $(n=8$ and $n=7$, respectively) were providing feedback at an average rate of once every 30 to 60 seconds. Although on average feedback rates were high, there was much variability between teachers, with one teacher providing nearly seven times as much feedback as another. Behets (1997) found that teachers $(n=9)$ provided feedback on average once every 19.48 seconds. van der Mars and associates (1998) reported that elementary school teachers $(n=18)$ provided mostly skill related or positive feedback at a rate of once every 16.09 seconds. Tan (1996) revealed that experienced teachers $(n=5)$ provided feedback on average once every 27.6 seconds and inexperienced teachers $(n=5)$ provided feedback once every 35.9 seconds. A more recent study by Spittle and associates (2012) observed that feedback was provided by PE teachers $(n=23)$ on average every 42.39 seconds.

In the studies reported here, there is some consistency in the type and frequency of feedback provided. Commonly, feedback was provided at rates of between once every 30- 
60 seconds of lesson time. In general, it is thought that teachers provide feedback during skill practice rather than game play, direct feedback to individuals rather than groups, and provide verbal feedback more often than non-verbal feedback (Siedentop, 1991). Feedback provided most often takes the form of non-skill related, positive evaluative statements and is used as a form of encouragement or motivation for students (Silverman, 1991). When skill related feedback is provided, KP is used at a much greater rate than KR (Fishman \& Tobey, 1978; Silverman et al., 1992; Silverman et al., 1998; Spittle et al., 2012).

In the studies reported, feedback frequencies between individual teachers varied substantially, with high standard deviations observed. In many of the studies, feedback events were not reported in relation to time spent in activity, rather in relation to overall lesson duration. In PE, teachers spend time on transitions between activities, explanations, demonstrations and skill presentations, meaning that students are not physically active for an entire lesson. These periods not only lessen the amount of time students spend in activity, but also the amount of time available to give feedback. To determine true rates of feedback frequency, only the times spent in activity should be used. Further information on actual frequencies of feedback in PE settings, including research on the amount of feedback received by individual students, is required to further understand effective teaching behavior.

\section{Experience and knowledge}

Provision of feedback is potentially associated with stronger pedagogical and content knowledge in PE, so that more effective teachers provide feedback more effectively (Ward, 2009), with the use of corrective, quantitative feedback indicative of pedagogical content knowledge of primary school teachers (Creasy, Whipp, \& Jackson, 2012) and more use of specific congruent feedback with improved content knowledge (Ward, Kim, Ko, \& Weidong, 2014). Pre-service teachers, because they are currently engaged in physical education teacher education (PETE) programs may be influenced in their use of feedback by their current pedagogical and content knowledge, which may mean that their use of feedback differs from more experienced teachers. Earlier studies on pre-service teachers have measured feedback use in simulated or peer learning situations. For example, Landin, Hawkins, Hebert, and Cutton (2001) reported that pre-service PE teachers $(n=14)$ provided descriptive feedback at an average rate of once every 87 seconds and prescriptive feedback every 25 seconds in the initial lesson in a peer-teaching exercise as part of their course. This rate of feedback provision appears to be similar to other studies with teachers. As feedback is considered an important teacher behavior, understanding how pre-service teachers use feedback and their perceptions surrounding their use of feedback may assist in developing more effective teacher behaviors in pre-service teachers.

\section{Perceptions of feedback use}

It is possible that teachers, and pre-service teachers, are not aware of how often and what types of feedback they provide. Part of being an effective teacher and creating effective learning environments is understanding and reflecting on your practice. Teacher perceptions of feedback behavior refer to the amount of feedback an instructor thinks that they are giving to their students or a class. Most research on perceptions of feedback behavior in PE has focused on students' perceptions rather than teachers' perceptions (Hastie \& Saunders, 1991; Nicaise, Cogerino, Fairclough, Bois, \& Davis, 2007). In the field of coaching, however, a few studies have observed coaches and subsequently asked 
coaches to recall their behaviors. These studies have found that most coaches are unaware of how frequently they performed certain behaviors (Smoll \& Smith, 2006; Millar, Oldham, \& Donovan, 2011). For example, Millar and associates (2011) examined the recall ability of rowing coaches on the timing, nature and content of feedback provided and found that coaches were largely inaccurate at recalling their feedback to athletes. Coaches gave more concurrent and prescriptive feedback and less terminal and descriptive feedback than they thought.

Whilst these studies have focused on the recall ability of coaches and not teachers, the results suggest that instructors in movement domains may not keep track of the frequency and type of feedback they are providing. We know little about how aware pre-service teachers are of how often and the types of feedback they provide in teaching. Exploring how well teachers recognize their teaching behaviors has implications for how they can become more effective in their teaching.

Studies on teacher feedback have not compared how pre-service teachers use feedback in peer-teaching and in actual teaching situations. Peer-teaching appears to be used frequently in PETE programs to provide experience of teaching to pre-service teachers, as well as to simulate the teaching experience. Typically in peer-teaching, pre-service teachers will be teaching their peers, that is, other pre-service teachers. One question that arises from this practice is how well this simulates or recreates the real authentic experience of teaching. For example, pre-service teachers may be more comfortable with their peers or teaching their peers may be confronting and may lead to less frequent feedback provision because of concerns related to their pedagogical content knowledge (Ward, 2009). Exploring how feedback varies between peer-teaching and actual teaching situations with pre-service teachers would help understanding the effectiveness of peer-teaching in PETE programs for influencing important teacher behaviors.

\section{Aims}

The purpose of this study was to explore the use of feedback and perceptions of the use of feedback by pre-service teachers in peer-teaching (instructing their peers in university classes) and practical placement settings (teaching in schools). The specific aims were to explore the frequency and type of feedback provided in peer-teaching settings; explore the frequency and type of feedback provided in practical placement settings; explore the perceived frequency and type of feedback used in peer-teaching; explore the perceived frequency and type of feedback used in practical placement; and compare actual and perceived feedback frequencies in peer-teaching and practical placement settings.

\section{METHODS}

\section{Participants}

Participants were 59 pre-service teachers (32 male aged 21.50 \pm 2.08 years, Mean \pm SD and 27 female aged $21.30 \pm 2.48$ years, Mean \pm SD). Pre-service teachers were all completing a 4-year Bachelor of Education (Prep to Year 12 [K-12]), specializing in primary PE and one other teaching method (e.g., health, math, science, English). Participants were recruited from a core primary PE unit, normally studied in the second year. The majority of participants 
$(n=44)$ reported being in their second year, with a further 14 participants in their third year and one student in their fourth year of study.

\section{Materials}

Participant demographic form

Participants completed a demographics form to provide information on their gender, age, year of their degree, and the number of PE units they had completed as part of their course.

\section{Feedback Observation System}

The Feedback Observation System was used to record feedback provided by the participants. The system was based on the measure used initially by Fishman and Tobey (1978) and adapted in various subsequent studies (Faucette \& Patterson, 1990; Silverman et al., 1992; Landin et al., 2001). Feedback observed during activity time in the lesson was recorded in the system. The type of feedback was initially classified as either skill-related feedback or non-skill-related feedback. The researcher also recorded whether the feedback was verbal on non-verbal and whether it was concurrent with or terminal to skill performance. Skill-related feedback was further classified as KP or KR, and as descriptive, prescriptive or corrective. Non skill-related feedback was classified as either positive or negative. A copy of the Feedback Observation System is available from the authors.

\section{Teacher Feedback Perception Response Sheet}

The Teacher Feedback Perception Response Sheet was developed by the researchers and was used by the pre-service teachers to record their perceptions of their own feedback behavior during the delivery of the lesson. The response sheet provided a definition along with an example of each type of feedback. The response sheet asked the participant to retrospectively recall the frequency of each type of feedback they felt they provided. A copy of the Teacher Feedback Perception Response Sheet is available from the authors.

\section{Procedure}

Ethics approval was granted by a University Human Research Ethics Committee as well as the State Department of Education and Training to conduct research in schools. Permission was granted by the lecturer in charge of the core primary PE unit studied by the pre-service teachers to recruit participants from that class. The unit was selected as it is a core unit and pre-service teachers complete a practical peer-teaching assessment in class. In addition to this, the pre-service teacher cohort completing the unit also participated in practical placement where they may have the opportunity to teach a PE lesson in schools. Participants were approached during class and asked to participate in the study. They were informed that participation was entirely voluntary and would not affect their performance or success in any unit. All sessions were observed and recorded by the same researcher.

\section{Peer-teaching setting}

Peer-teaching data was collected during tutorials. All participants delivered a 15-minute PE lesson to their peers, focused on teaching a particular primary school dance, such as the 
'Honky Tonk Stomp', 'Men in Black' and the 'Cowboy Hustle'. Each dance taught by the participants differed, and was determined by the unit tutor earlier in the semester. The data collection procedure for the peer-teaching setting followed the following steps: participants were asked to complete a Participant Demographic Form prior to lesson delivery; participants delivered the lesson and feedback frequency data was collected using the Feedback Observation System; and after delivery of the lesson, participants completed the Teacher Feedback Perception Response Sheet. Participants were filmed in these sessions, with all class members having signed a statement to consent for filming. Filming allowed for time spent in activity to be calculated, as well as observer reliability to be measured on the Feedback Observation System, by comparing live and video coding for all participants. Video coding was completed 4 weeks after live coding.

\section{Practical placement setting.}

Practical placement setting. A cohort of six participants were further observed while teaching a PE lesson as a part of their practical placement period in schools. Permission was sought to collect data in the school, and a time was organized to observe the participant teach a PE lesson. Year levels of the primary school students being taught ranged from Prep to Grade 4 (age 5-10 years), and a number of sports and activities were taught including football, basketball, and general game play.

A similar protocol was used while collecting data during practical placement with feedback frequency data collected during the delivery of each lesson using the Feedback Observation System. In practical placement settings, however, filming during the lesson was not conducted. Following delivery of the lesson, participants were again asked to complete the Teacher Feedback Perception Response Sheet.

\section{Data Analysis}

Descriptive statistics and frequencies were used to analyze the demographic data collected. Descriptive statistics were also used to determine mean frequencies of the different types of feedback in both the peer-teaching and placement settings. To aid in comparison of feedback frequencies, frequency is reported as the frequency of feedback provided per minute of activity. Paired sample t-tests were used to compare differences between actual and perceived feedback frequencies for each type of feedback in both settings. Cohen's d was calculated to determine effect size of the differences between actual and perceived feedback behaviors of pre-service teachers. Pearson correlations were calculated to determine reliability between live observation coding and coding of sessions observed on video.

\section{RESULTS}

\section{Peer-teaching Setting}

\section{Actual feedback frequency}

The mean feedback frequencies in peer-teaching settings for each type of feedback are presented in Table 1. The average total feedback for all participants in the peer-teaching setting was 1.08 feedback times per minute, equating to providing feedback every 56 seconds during activity. Verbal feedback was provided at a greater rate than non-verbal feedback, with non-verbal feedback provided on average every six minutes and 40 seconds, whereas 
verbal feedback was provided on average every 65 seconds. The most common type of feedback was positive, non-skill related feedback, and was provided by participants once every 87 seconds. The least frequent type of feedback provided by participants was negative, skill related feedback, provided at a rate once every 100 minutes of activity. When participants did provide skill-related feedback, it was most often prescriptive KP. Terminal feedback was provided more often than concurrent feedback.

\section{Perceived feedback frequency}

Descriptive statistics in Table 1 reveal that participants perceived that they gave feedback 1.46 times per minute of activity. This equates to providing feedback every 41 seconds. Participants perceived that they gave more non-verbal than verbal feedback, reporting non-verbal feedback on average every 76 seconds and verbal feedback every 91 seconds. The feedback type that participants perceived they gave the most was again positive, non-skill related feedback, perceived at a rate of once every 2 minutes and 38 seconds. The least common type of feedback was, as reported in the actual frequencies, negative, non-skill related feedback, at an average rate of once every 16 minutes and 40 seconds. Pre-service teachers also perceived they provided feedback during the performance of skill (concurrent) as often as they provided feedback after performance (terminal).

Table 1 Actual and Perceived Feedback Frequency in Peer-teaching Setting

\begin{tabular}{|c|c|c|c|c|c|c|c|}
\hline \multirow[b]{2}{*}{ Feedback type } & \multicolumn{2}{|c|}{ Actual } & \multicolumn{2}{|c|}{ Perceived } & \multirow[b]{2}{*}{$p$} & \multirow[b]{2}{*}{$t$} & \multirow[b]{2}{*}{ Cohen's $d$} \\
\hline & $M$ & $S D$ & $M$ & $S D$ & & & \\
\hline Verbal & 0.92 & 0.37 & 0.66 & 0.44 & 0.00 & 4.84 & 0.67 \\
\hline Non-Verbal & 0.15 & 0.27 & 0.79 & 0.65 & 0.00 & -7.83 & -1.29 \\
\hline Non-Skill & 0.70 & 0.36 & 0.41 & 0.43 & 0.00 & 4.06 & 0.73 \\
\hline Positive & 0.69 & 0.36 & 0.38 & 0.41 & 0.00 & 4.45 & 0.80 \\
\hline Negative & 0.01 & 0.05 & 0.06 & 0.15 & 0.01 & -2.77 & -0.45 \\
\hline Skill & 0.35 & 0.23 & 0.32 & 0.28 & 0.57 & 0.57 & 0.12 \\
\hline KR & 0.01 & 0.10 & 0.21 & 0.30 & 0.00 & -4.54 & -0.89 \\
\hline $\mathrm{KP}$ & 0.35 & 0.23 & 0.15 & 0.26 & 0.00 & 4.53 & 0.81 \\
\hline Descriptive & 0.05 & 0.10 & 0.16 & 0.28 & 0.01 & -2.56 & -0.52 \\
\hline Prescriptive & 0.27 & 0.18 & 0.16 & 0.19 & 0.00 & 3.91 & 0.59 \\
\hline Corrective & 0.03 & 0.06 & 0.16 & 0.23 & 0.00 & -4.12 & -0.77 \\
\hline Concurrent & 0.31 & 0.30 & 0.44 & 0.52 & 0.09 & -1.72 & -0.30 \\
\hline Terminal & 0.74 & 0.39 & 0.38 & 0.38 & 0.00 & 5.07 & 0.93 \\
\hline Total & 1.08 & 0.49 & 1.46 & 0.83 & 0.00 & 5.01 & -0.56 \\
\hline
\end{tabular}

Note: Feedback is reported as frequency per minute of activity during the lesson

\section{Comparison of actual and perceived feedback frequencies}

There were significant differences between actual and perceived feedback frequencies for 11 of the 13 feedback types. Cohen's d values indicated moderate to large effect sizes. Participants perceived that they provided significantly more feedback than they were observed providing for non-verbal, negative, $\mathrm{KR}$, descriptive, and corrective types of feedback. Participants actually provided more feedback than they perceived that they had provided for verbal, non-skill related, positive, KP, prescriptive, and terminal feedback. There were no significant differences between actual and perceived frequencies for skillrelated and concurrent feedback. 


\section{Practical Placement Setting}

\section{Actual feedback frequency}

The feedback frequencies in practical placement settings are presented in Table 2. Average total feedback provision for participants in the practical placement setting was 0.70 times per minute, equating to providing feedback on average every 86 seconds. Preservice teachers provided verbal feedback more often than non-verbal feedback, with verbal feedback being provided at a rate of once every 50 seconds, whereas non-verbal feedback was provided at a rate of once every 14 minutes and 17 seconds. The most common type of feedback provided was positive non-skill related feedback at an average rate of once every 80 seconds. Corrective skill-related feedback was the least frequent form of feedback, provided at an average rate of once every 33 minutes and 20 seconds.

\section{Perceived feedback frequency.}

Perceived feedback frequencies in practical placement settings in schools are displayed in Table 2. Pre-service teachers perceived that on average they provided feedback 0.90 times per minute, equating to providing feedback on average every 66 seconds during activity. They perceived that they provided verbal feedback often, at a rate of once per one minute and 45 seconds of activity. This was often non-skill related feedback, at a rate of once per 88 seconds, perceived most often as positive feedback. Pre-service teachers also perceived that they most often provided concurrent feedback.

\section{Comparison of actual and perceived feedback frequencies.}

Paired sample t-tests indicated that there were no differences between actual and perceived feedback frequencies for most forms of feedback (Table 2). There was a significant difference for non-verbal feedback, with participants perceiving that they provided more non-verbal feedback than what was observed. Cohen's $d$ value indicated a large effect size.

Table 2 Actual and Perceived Feedback Frequency in Practical Placement Setting

\begin{tabular}{|c|c|c|c|c|c|c|c|}
\hline \multirow[b]{2}{*}{ Feedback type } & \multicolumn{2}{|c|}{ Actual } & \multicolumn{2}{|c|}{ Perceived } & \multirow[b]{2}{*}{$p$} & \multirow[b]{2}{*}{$t$} & \multirow[b]{2}{*}{ Cohen's $d$} \\
\hline & $M$ & $S D$ & $M$ & $S D$ & & & \\
\hline Verbal & 1.20 & 1.23 & 0.57 & 0.83 & 0.12 & -1.86 & 0.60 \\
\hline Non-Verbal & 0.07 & 0.04 & 0.32 & 0.31 & 0.01 & 3.78 & -1.13 \\
\hline Non-Skill & 0.80 & 0.81 & 0.62 & 0.84 & 0.23 & -1.36 & 0.22 \\
\hline Positive & 0.75 & 0.79 & 0.68 & 0.80 & 0.53 & -0.68 & 0.09 \\
\hline Negative & 0.05 & 0.04 & 0.27 & 0.43 & 0.33 & 1.08 & -0.72 \\
\hline Skill & 0.48 & 0.47 & 0.44 & 0.54 & 0.51 & -0.72 & 0.08 \\
\hline KR & 0.08 & 0.08 & 0.15 & 0.30 & 0.77 & 0.31 & -0.32 \\
\hline $\mathrm{KP}$ & 0.39 & 0.44 & 0.23 & 0.27 & 0.64 & -0.49 & 0.44 \\
\hline Descriptive & 0.12 & 0.14 & 0.32 & 0.45 & 0.97 & 0.04 & -0.60 \\
\hline Prescriptive & 0.32 & 0.42 & 0.30 & 0.43 & 0.76 & -0.33 & 0.05 \\
\hline Corrective & 0.03 & 0.07 & 0.24 & 0.44 & 0.42 & -0.88 & -0.67 \\
\hline Concurrent & 0.24 & 0.25 & 0.65 & 0.88 & 0.41 & 0.90 & -0.63 \\
\hline Terminal & 1.04 & 1.02 & 0.30 & 0.40 & 0.20 & -1.47 & 0.96 \\
\hline Total & 0.70 & 0.64 & 0.90 & 1.13 & 0.76 & 0.33 & -0.22 \\
\hline
\end{tabular}

Note: Feedback is reported as frequency per minute of activity during the lesson 


\section{Observation reliability}

Pearson correlations revealed strong relationships between feedback frequencies of live codings and subsequent coding of video footage, supporting the reliability of the feedback frequency measure used. The weakest correlation was for negative feedback at .68, with non-verbal feedback at .83 and all other correlations above .90, including verbal (.95), nonskill (.96), positive (.97), skill (.99), KR (1.00), KP (.97), descriptive (1.00), prescriptive (.98), corrective (1.00), concurrent (.91), and terminal (.97).

\section{DISCUSSION}

This study describes the use of feedback and perceptions of the use of feedback by preservice teachers in peer-teaching (instructing their peers in university classes) and practical placement settings (teaching in schools). Pre-service teachers provided feedback at an average rate of 1.08 times per minute (or every 56 seconds) in peer-teaching, while in practical placement pre-service teachers provided feedback at an average rate of .70 times per minute (or every 86 seconds).

While research on feedback frequencies has received some attention in recent times (Kim \& Housner, 2010; Spittle et al., 2012) the feedback behaviors of pre-service teachers is an area that is yet to be extensively investigated. The rate of feedback provision in peerteaching is similar to previous studies with more experienced PE teachers in actual teaching settings, which has generally reported average rates of feedback provision of every 30 to 60 seconds (Siedentop, 1991; Spittle et al., 2012). The rate of feedback provision by the pre-service teachers on practical placement, however, was somewhat less frequent. Rates may be lower in the practical setting because the pre-service teachers feel less confident than in the peer-teaching environment or in comparison to more experienced teachers. This could be due to experience and content knowledge. Provision of feedback is potentially associated with stronger pedagogical and content knowledge in PE (Ward, 2009; Ward et al., 2014). This suggests that although peer-teaching provides a simulation of teaching, it may not always recreate the real authentic experience of teaching. For example, pre-service teachers may be more comfortable with their peers than when working with a supervising teacher or when teaching a group of students.

The standard deviations for the mean feedback frequencies indicate that there was much variability in frequency of feedback among participants. Previous studies that have measured feedback frequencies in PE have found similar high standard deviations among participants (Tan, 1996; Silverman et al., 1998; Spittle et al., 2012). So although the average rates of provision were every 56 seconds in peer-teaching and 86 seconds in practical placement, some pre-service PE teachers were providing feedback a lot more than this, and others a lot less. Future research could potentially explore why these differences occurred and how preservice teachers (e.g., those with more or less pedagogical content knowledge) use feedback.

Pre-service teachers provided more non-skill related feedback than skill related feedback in both peer-teaching and practical placement settings. Non-skill related feedback was provided on average every 86 seconds in peer-teaching and every 171 seconds in practical placement, whereas skill related feedback was provided every 75 seconds in peerteaching and 125 seconds in practical placement. This result is consistent with previous findings where the most common type of feedback provided is non-skill related positive feedback (see review Silverman et al., 1998). A possible explanation for a greater frequency of 
non-skill related feedback in the current study may be experience and content knowledge of the pre-service teachers. Researchers have suggested that provision of feedback is potentially associated with stronger pedagogical and content knowledge in PE (Ward, 2009; Ward et al., 2014). Further, pedagogical content knowledge has been linked to the use of corrective, quantitative feedback (Creasy et al., 2012). Having less experience and potentially lower pedagogical and content knowledge could mean that pre-service teachers provided less skill related feedback pertaining to technical instruction and correcting errors as they were unsure of errors in movement or did not know what to look for. The non-skill related feedback was predominantly positive feedback and may have been used to keep learners on task and motivated (Koka \& Hein, 2005). As the learning situations, especially peer-teaching, may be perceived to be a controlled environment, a focus on behavior management may have been reduced. Pedagogical and content knowledge was not a factor measured in the current study and, therefore, may be an area for future research.

Nearly all of the skill related feedback provided by the pre-service teachers was KP rather than KR, suggesting a focus on the process of movement or technique rather than the outcome of the movement. The pre-service teachers provided KP on average every 171 seconds in peer-teaching and every 154 seconds in practical placement, whereas they only provided KR every 100 minutes in peer-teaching or 12 minutes and 30 seconds in practical placement. Studies of PE teachers also suggest that teachers provide significantly more KP than KR (Fishman \& Tobey, 1978; Spittle et al., 2012), although the differences between the rates of provision appear to be more pronounced in the current study. Motor learning textbooks generally suggest that KP is more often useful for the learner than KR and so should be provided more often (Spittle, 2013; Magill \& Anderson, 2020). This is because KR is easier for learners to determine for themselves without the assistance of the instructor or teacher than KP. The outcome of movement is often obvious and inherent in the skill because learners immediately know the result of the skill attempt, whereas movement technique or form can be more difficult for the learner to perceive for themselves (Spittle, 2013). It appears that preservice teachers understood this concept. Although KR was rarely provided, it was anecdotally noted that the most common situation it was observed occurring in practical placement was when pre-service teachers took on an umpiring or scoring role during game play in a game or sport.

Participants perceived that they provided feedback on average every 41 seconds in peerteaching and every 66 seconds in practical placement. They perceived that they provided significantly more feedback in peer-teaching than they actually did (every 41 seconds versus every 56 seconds). This suggests that the pre-service teachers were overestimating how often they were providing feedback. Although previous research has not compared perceptions and actual feedback use of PE pre-service teachers, research with coaches has suggested that they overestimated the amount of feedback they provided (Millar et al., 2011). Millar et al. suggested that this could be because coaches know what to do, but may have difficulty performing the behavior. They explained that the differences between perceived and actual feedback were unlikely to be due to social desirability bias, as participants were aware that their behavior was being reported, but was more likely to be due to confirmation bias, where participants recalled behaviors in a way that was consistent with their personal beliefs about themselves.

By overestimating the amount of feedback provided, it suggests that the pre-service PE teachers may not be completely aware of their use of feedback. Developing awareness of feedback use may help pre-service PE teachers use feedback more effectively. De Marco 
and Mario (1997) found that making coaches aware of their behavior improved their perceptions, even though they still overestimated. Increasing reflective behavior of preservice teachers may increase self-awareness and help the pre-service PE teachers become more reflective practitioners. Examples of activities that may be relevant in PE include reviewing peer-teaching at the end of sessions and using video sessions to provide feedback to the pre-service teachers.

There were also differences between perceptions and actual use of specific types of feedback in the peer-teaching setting. Participants perceived that they provided significantly more feedback than they were observed actually providing for non-verbal, negative, KR, descriptive, and corrective types of feedback. Participants actually provided more feedback than they perceived that they had for verbal, non-skill related, positive, KP, prescriptive, and terminal types of feedback. Thus, pre-service teachers both under and over-estimated their use of the different types of feedback. Again, although there is limited evidence in PE, Millar and associates' study (2011) on recall ability of rowing coaches found that coaches were largely inaccurate at recalling their instructions and feedback to athletes. Coaches perceived that they provided more evaluative and affective feedback; however, they were observed providing very high levels of prescriptive feedback. The results of this study, together with those of sport coaching research, however, suggest pre-service physical educators in general can be inaccurate in their recall of feedback behavior.

The current study provides useful information about use and perceptions of use of feedback provided by PE pre-service teachers while peer-teaching and also while teaching on practical placement. The research settings in which the study was conducted are authentic to PETE and occurred as they would if the research was not being conducted. Research in the peer-teaching setting was conducted during actual classes at the university and no aspect of the practical placement setting was altered. Participants were able to structure their lessons as they saw fit and select sports and activities of their choice. This allowed the current study to examine feedback frequencies in a general sense, rather than limiting the study to one sport or lesson topic. The research in the peer-teaching setting used a larger sample $(n=59)$ than previous research on feedback use on PE, which has generally studied fewer than 20 participants (Spittle et al., 2012). Despite this, there are some potential limitations of the current study that should be acknowledged. For example, although the sample size for the peer-teaching setting was large in comparison to previous research, the sample size for the practical placement setting was very small, with only six participants. The measure used to record feedback frequencies was developed by the researchers for the study as there was no established measure of the feedback use of pre-service PE teachers and the specific types of feedback of interest. The measure was developed based on approaches used in previous research (e.g., Faucette \& Patterson, 1990; Silverman et al., 1992; Landin et al., 2001). There was also no available measure of perceptions of feedback use, so this measure was also developed for the current study. Consequently, there is no previous reliability and validity information on these measures. We did, however, test for reliability of the feedback use measure by comparing live coding of feedback frequency and video footage viewed later, which revealed strong relationships between scores, supporting its reliability.

The limitations of the study provide some directions for future research. Increasing the sample size, especially in the practical setting would allow for more comparisons to be made between settings. The use of authentic settings provided for more naturalistic observations and should be used in future research. To expand research of pre-service teacher behaviors such as feedback use, valid and reliable instruments to record the behaviors of interest are 
needed and future research could work to create psychometrically validated measures to support research. This study explored pre-service teachers; however, the use of feedback by experienced teachers is also not well understood and could be targeted in future research given the perceived importance of feedback provision as a teaching behavior. Results in the current study found that more non-skill related feedback was provided than skill-related feedback by pre-service teachers. An investigation into the reason(s) for this difference may give more insight into the lesson goals of PE pre-service teachers and whether there is more emphasis on student motivation or skill acquisition. The findings of the current study suggest that pre-service teachers were providing less feedback than more experienced PE teachers. It is currently unknown as to why this occurs.

\section{CONCLUSIONS}

In conclusion, this study demonstrates that pre-service teachers provided feedback frequently in peer-teaching and practical placement settings, but differed in their use of feedback in peer-teaching versus practical placement settings, with feedback provided more often in peer-teaching. Actual and perceived feedback frequencies did not always match and suggest that pre-service teachers may not always be aware of how often and the type of feedback they are providing, highlighting that PETE programs may need to work with pre-service teachers to develop self-awareness and provide opportunities for authentic leaning experiences to ensure that pre-service teachers have opportunities to learn about and practice this teaching skill.

Acknowledgement: The authors sincerely thank the Department of Education and Training (Victoria, Australia) for providing permission to conduct research in schools. We also thank the schools involved in the research as well as the supervising teachers, lecturers of units, students, and participants who made this study possible. The authors received no financial support for research, authorship, and/or publication of this article.

\section{REFERENCES}

Australia Institute for Teaching and School Leadership (2011). Australian Professional Standards for Teachers. Canberra: Education Services Australia. Retrieved from the World Wide Web on July 15, 2020: http://www.aitsl.edu.au/australian-professional-standards-for-teachers/

Behets, D. (1997). Comparison of more and less effective teaching behaviors in secondary physical education. Teaching and Teacher Education, 13(2), 215-224.

Creasy, J., Whipp, P., \& Jackson, B. (2012). Teachers' pedagogical content knowledge and students' learning outcomes in ball game instruction. ICHPER - SD Journal of Research in Health, Physical Education, Recreation, Sport and Dance, 7(1), 3-11.

De Marco, G., \& Mario, P.A. (1997). Qualitative and quantitative analysis of a baseball coach's behaviour. Journal of Sport Behavior, 20(2), 135-164.

Faucette, N., \& Patterson, P. (1990). Comparing teaching behaviors and student activity levels in classes taught by P.E. specialists versus nonspecialists. Journal of Teaching in Physical Education, 9, 106-114.

Fishman, S., \& Tobey, C. (1978). Augmented feedback. In W.G. Anderson \& G.T. Barrette (Eds.), What's going on in gym: Descriptive studies of physical education classes. Newton, CT: Motor Skills: Theory Into Practice.

Fredenburg, K.B., Lee, A.M., \& Solmon, M. (2001). The effect of augmented feedback on students' perceptions and performance. Research Quarterly for Exercise and Sport, 72(3), 232-242.

Hastie, P.A., \& Saunders, J.E. (1991). Accountability in secondary school physical education. Teaching and Teacher Education, 7(4), 373-382. 
Kernodle, M., \& Carlton, L. (1992). Information feedback and the learning of multiple-degree-of-freedom activities. Journal of Motor Behavior, 24, 187-196.

Kim, H.Y., \& Housner, L.D. (2010). The influence of class size on the planning decision making, concerns, and instructional behaviors of experienced and inexperienced teachers. International Journal of Applied Sports Sciences, 22(2), 77-95.

Koka, A., \& Hein, V. (2005). The effect of perceived teacher feedback on intrinsic motivation in physical education. International Journal of Sport Psychology, 36, 91-106.

Landin, D.K., Hawkins, A., Hebert, E., \& Cutton, D. (2001). Improving the feedback ability of teacher trainees. Education, 110(1), 98-107.

Lee, A.M., Keh, N.C., \& Magill, R.A. (1993). Instructional effects of teacher feedback in physical education. Journal of Teaching in Physical Education, 12, 228-243.

Magill, R.A., \& Anderson, D. (2020). Motor learning and control: Concepts and applications $\left(12^{\text {th }}\right.$ Ed.). New York, NY: McGraw-Hill.

Maksimović, J., \& Osmanović, J. (2018). Physical education teachers as reflective practitioners and action researchers in their work. Facta Universitatis Series Physical Education and Sport, 16(2), 375-386

Metzler, M. (2011). Instructional models for physical education (3rd Ed.) Scottsdale, AZ: Holcombe Hathaway.

Metzler, M. (2014). Teacher effectiveness research in physical education: The future isn't what it used to be. Research Quarterly for Exercise and Sport, 85(1), 14-19.

Millar, S., Oldham, A., \& Donovan, M. (2011). Coaches' self awareness of timing, nature and intent of verbal instructions to athletes. International Journal of Sports Science and Coaching, 6(4), 503-513.

Nicaise, V., Cogerino, G., Fairclough, S., Bois, J., \& Davis, K. (2007). Teacher feedback and interactions in physical education: Effects of student gender and physical activities. European Physical Education Review, 13(3), 319-337.

Rink, J. (2003). Effective instruction in physical education. In S.J. Silverman and C.D. Ennis (Eds.), Student learning in physical education: Applying research to enhance instruction (2nd ed., pp. 165-186). Champaign, IL: Human Kinetics.

Rink, J. (2020). Teaching physical education for learning ( $8^{\text {th }}$ Ed.). Boston, MA: McGraw-Hill.

Rink, J. (2014). Teacher effectiveness in physical education - Consensus? Research Quarterly for Exercise and Sport, 85(1), 282-286.

Salmoni, A., Schmidt, R.A., \& Walter, C. (1984). Knowledge of results and motor learning: A review and critical appraisal. Psychological Bulletin, 95, 355-386.

Siedentop, S. (1991). Developing teaching skills in physical education ( $3^{\text {rd }}$ Ed.). Mountain View, CA: Mayfield.

Silverman, S. (1991). Research on teaching in physical education. Research Quarterly for Exercise and Sport, $62(4), 352-264$

Silverman, S. (1994). Communication and motor skill learning: What we learn from research in the gymnasium. Quest, 46, 345-355.

Silverman, S., Tyson, L., \& Krampitz, J. (1992). Teacher feedback and achievement in physical education: interaction with student practice. Teaching \& Teacher Education, 8(4), 333-344.

Silverman, S., Woods, A.M., \& Subramaniam, P.R. (1998). Task structures, feedback to individual students, and student skill level in physical education. Research Quarterly for Exercise and Sport, 69(4), 420-424.

Smoll, F., \& Smith, R. (2006). Development and implementation of coach-training programs. In J. Williams (Ed.), Applied sport pyschology: Personal growth to peak performance ( ${ }^{\text {th }}$ Ed.), (pp. 458-480). Boston, MA: McGraw-Hill.

Spittle, M. (2013). Motor learning and skill aquisition: Application in physical education and sport. Melbourne: Palgrave-Macmillan.

Spittle, M., Kennedy, M., \& Spittle, S. (2012). Frequency of teacher augmented feedback and teaching style in secondary physical education. The Global Journal of Health and Physical Education Pedagogy, 1(3), 173-188.

Tan, S.K.S. (1996). Differences between experienced and inexperienced physical education teachers' augmented feedback and interactive teaching decisions. Journal of Teaching in Physical Education, 15(2), 151-170.

van der Mars, H., Vogler, B., Darst, P., \& Cusimano, B. (1998). Students' physical activity levels and teachers' active supervision during fitness instruction. Journal of Teaching in Physical Education, 18, 57-75.

Ward, P. (2009). Content matters: Knowledge that alters teaching. In L. Housner, M. Metzler, P. Schempp, \& T. Templin (Eds.), Historic traditions and future directions of research on teaching and teacher education in physical education, (pp. 345-356). Morgantown, WV: Fitness Information Technology.

Ward, P. (2014). A response to the conversations on effective teaching in physical education. Research Quarterly for Exercise and Sport, 85, 293-296.

Ward, P., Kim, I., Ko, B., \& Weidong, L. (2014). Effects of improving teachers' content knowledge on teaching and student learning in physical education. Research Quarterly for Exercise and Sport, 86(2), 130-139.

Winstein, C.J., \& Schmidt, R.A. (1990). Reduced frequency of knowledge of results enhances motor skill learning. Journal of Experimental Psychology: Learning Memory and Cognition, 16, 677-691. 


\section{UPOTREBA POVRATNIH INFORMACIJA I PERCEPCIJE NASTAVNIKA FIZIČKOG VASPITANJA U PRE-SLUŽBI}

Cilj ovog istraživanja bio je da istraži upotrebu povratnih informacija i percepciju upotrebe povratnih informacija od strane nastavnika u pre-službi vršnjačke nastave tj., podučavanje svojih vršnjaka tokom univerzitetske nastave i nastave u školama. Nastavnici pre-službe specijalizovani za osnovno fizičko vaspitanje (FV) i još jednu nastavnu metodu (n=59) posmatrani su tokom 15-minutnog predavanja u vršnjačkom okruženju, dok je šestoro nastavnika takođe, posmatrano tokom držanja praktične nastave. Nastavnici su se retrospektivno prisetili povratnih informacija koje su pružali tokom lekcije. Prosečna stopa učestalosti povratnih informacija bila je jednom u 56 sekundi u vršnjačkoj nastavi i jednom u 86 sekundi u praktičnoj nastavi. Najčešća vrsta povratnih informacija bila je verbalna, pozitivna povratna informacija koja se ne odnosi na veštine. Nastavnici u pre-službi uočili su da povratne informacije pružaju znatno češće nego što su to zapravo učinili (svake 41 sekunde naspram svakih 56 sekundi u vršnjačkoj nastavi). U vršnjačkoj nastavi, nastavnici u pre- službi zapazili su da pružaju znatno više neverbalnih, negativnih, znanja o rezultatima, opisnih i korektivnih vrsta povratnih informacija nego što su zapravo pružali, dok su smatrali da su pružili znatno manje verbalnih, neverbalnih pozitivnih, povezanih sa veštinama, o poznavanju učinka, preskriptivnih i terminalnih vrsta povratnih informacija, nego što su stvarno pružali $(p<.01)$. Nastavnici su često pružali povratne informacije u vršnjačkom podučavanju i praktičnoj nastavi, ali ređe tokom praktične nastave u odnosu na podučavanje u vršnjačkom okruženju. Stvarne i uočene frekvencije povratnih informacija znatno su se razlikovale i sugerišu da nastavnici u pre-službi možda nisu uvek svesni koliko često i koju vrstu povratnih informacija pružaju, ističući da će u okviru obrazovnih programa nastavnika fizičkog vaspitanja biti neophodno da se radi na razvoju samosvesnosti.

Ključne reči: znanje o performansama, znanje o rezultatima, efikasnost nastavnika, fizičko vaspitanje, motorno učenje 